\title{
The Impacts of Hydropower Dams in the Mekong River Basin: A Review
}

\author{
Akarath Soukhaphon ${ }^{1, *}$, Ian G. Baird ${ }^{1}\left(\mathbb{D}\right.$ and Zeb S. Hogan ${ }^{2}$ \\ 1 Department of Geography, University of Wisconsin-Madison, Madison, WI 53706, USA; ibaird@wisc.edu \\ 2 Department of Biology and Global Water Center, University of Nevada, Reno, NV 89557, USA; \\ zhogan@unr.edu \\ * Correspondence: soukhaphon@wisc.edu; Tel.: +1-414-368-7465
}

check for updates

Citation: Soukhaphon, A.; Baird, I.G.; Hogan, Z.S. The Impacts of Hydropower Dams in the Mekong River Basin: A Review. Water 2021, 13, 265. https://doi.org/10.3390/ w13030265

Received: 4 December 2020

Accepted: 20 January 2021

Published: 22 January 2021

Publisher's Note: MDPI stays neutral with regard to jurisdictional claims in published maps and institutional affiliations.

Copyright: (C) 2021 by the authors. Licensee MDPI, Basel, Switzerland. This article is an open access article distributed under the terms and conditions of the Creative Commons Attribution (CC BY) license (https:// creativecommons.org/licenses/by/ $4.0 /)$.

\begin{abstract}
The Mekong River, well known for its aquatic biodiversity, is important to the social, physical, and economic health of millions living in China, Myanmar, Laos, Thailand, Cambodia, and Vietnam. This paper explores the social and environmental impacts of several Mekong basin hydropower dams and groupings of dams and the geographies of their impacts. Specifically, we examined the 3S (Sesan, Sekong Srepok) river system in northeastern Cambodia, the Central Highlands of Vietnam, and southern Laos; the Khone Falls area in southern Laos; the lower Mun River Basin in northeastern Thailand; and the upper Mekong River in Yunnan Province, China, northeastern Myanmar, northern Laos, and northern Thailand. Evidence shows that these dams and groupings of dams are affecting fish migrations, river hydrology, and sediment transfers. Such changes are negatively impacting riparian communities up to $1000 \mathrm{~km}$ away. Because many communities depend on the river and its resources for their food and livelihood, changes to the river have impacted, and will continue to negatively impact, food and economic security. While social and environmental impact assessments have been carried out for these projects, greater consideration of the scale and cumulative impacts of dams is necessary.
\end{abstract}

Keywords: Mekong; hydropower; livelihoods; fisheries

\section{Introduction}

\subsection{The Mekong River and the Cumulative Impacts of Dams}

With a length of $4909 \mathrm{~km}$ beginning in China and flowing through Myanmar, Thailand, Laos, Cambodia, and Vietnam before emptying into the South China Sea [1], the Mekong River and its tributaries constitute one of the most important freshwater aquatic systems in the world, with globally significant aquatic biodiversity, aquatic biological production, and connection to human livelihood. More than 65 million people live in the Mekong River Basin, $40 \%$ of whom reside within $15 \mathrm{~km}$ of the mainstream Mekong itself. Many of these people depend on the river for food security, livelihood, and trade [2]. The river is unique in that annual variations between low and high water volumes are greater in the Mekong than for any other large river in the world, resulting in a variety of environmental conditions and habitats critical for a high diversity of aquatic life [3]. However, the Mekong River Basin has experienced a number of critical changes over the last few decades, particularly due to the development of a large number of hydropower dams. Many of these projects have caused serious social and environmental impacts, ones with implications far beyond the locations where the projects were constructed. Thus, the particular geographies of the social and environmental impacts of hydropower dams in the Mekong River Basin are crucial to consider.

Here, we review the history of large-scale hydropower dam development in the Mekong River Basin, including some of the most important social and environmental implications of the most prominent hydropower projects. We then specifically consider the geographies of the social and environmental impacts of four particular dams or groupings 
of dams, and the broad geographies and interconnections between different projects. These include the 3S (Sesan, Sekong, Srepok) river system in northeastern Cambodia; the Central Highlands of Vietnam and southern Laos; the Khone Falls area in southern Laos; the lower Mun River Basin in northeastern Thailand; and the upper Mekong River in Yunnan Province, China, northeastern Myanmar, northern Laos, and northern Thailand.

We argue that understanding the different kinds of geographies associated with the Mekong River Basin-biological, hydrological, human, infrastructure, and energy -is crucial for assessing the implications of hydropower development, including its political ecologies and uneven, broad, and cumulative impacts. Such geographies include the politics of scale and the spatial extent of different social and environmental impacts. For example, understanding where water governance decisions are made and where the energy is produced and ultimately consumed provide insights into the uneven power relations between local peoples and national and regional governing bodies. Similarly, evidence of different impacts at various spatial scales calls for a re-evaluation of the limited scope of past and current impact analyses of hydropower projects.

\subsection{A Brief History of Hydropower Dam Building in the Mekong River Basin}

Hydropower dam development in the Mekong River Basin began in northeastern Thailand when the Nam Pung Dam was built in Sakon Nakhorn Province in November 1965. The Nam Pong Dam, in the upper Chi River Sub-basin in Khon Kaen Province, was developed soon after, and was officially inaugurated in March 1966. The Ubol Ratana Dam was completed in the same year, and the Lam Pao Dam was operational by 1968. The Sirindhorn Dam was completed in the Mun River Basin in Ubon Ratchathani Province in 1971, and the Chulabhorn Dam was operational by 1972 [4]. The first large dam in Laos, the Nam Ngum Dam, in central Laos, was completed in 1971 [5]. However, Cold War conflict prevented many of the dams envisioned for the Mekong River Basin between the 1960s and 1980s from being constructed [6].

Largely due to Cold War conflict, hydropower dam development in the region did not seriously begin again until the Pak Mun Dam began being constructed on the Mun River, the most important Mekong tributary in Thailand, in Ubon Ratchathani in 1990 [7,8]. During the 1990s, the government of Thailand also started developing other medium and large irrigation dams, as part of the Khong-Chi-Mun Scheme [9,10]. In the mid-1990s, dam construction in Laos also began again with the support of foreign investment, including the construction of the Houay Ho Dam in southern Laos, the Theun-Hinboun Dam in central Laos, and a few other dams [11-13]. In China, the first dam on the Lancang (Mekong) River was also constructed in the 1990s, with the Manwan Dam being completed in 1993 [14]. In the Central Highlands of Vietnam, construction of the Yali Falls Dam began in 1993, and was completed in $2001[15,16]$.

However, the 1998-1999 Asian financial crisis resulted in some planned hydropower projects being cancelled, while others were postponed or scaled down. For example, in 1996, South Korea's Dong Ah Construction Industries Company agreed to build the Xe Pian Xe Namnoy Dam in southern Laos. Construction work had begun, but due to financial difficulties in Korea, the project was discontinued, and Dong Ah withdrew entirely in 1999 [12,17], although the project was revived by another Korean company in the 2010s [18]. Other projects envisioned for the Sekong River in southern Laos were also cancelled. Similarly, the Energy Generating Authority of Thailand (EGAT) had previously agreed to invest in the construction of China's Jinghong Dam, but withdrew from the project in 2000 due to the financial crisis and associated lack of energy demand in Thailand [19].

Due to a decline in market demand for hydropower energy, and lingering financial difficulties associated with the Asian financial crisis, little hydropower development occurred in the lower Mekong River Basin during the early 2000s [17]. The critical findings of the negative social and environmental costs of dams by the World Commission on Dams [20] also discouraged large institutions from funding new large dams in the early 2000s. However, hydropower dam development continued on the mainstream Lancang 
River in China [21], and in 2005, the World Bank approved the controversial Nam Theun 2 Hydropower Project in central Laos, at the time the largest dam ever built in the entire Mekong River Basin. It became operational in 2010 [22,23].

In the 2010s, hydropower dam development increased dramatically, particularly in Laos, China, and Cambodia. In Laos, as of February 2019, there were 61 hydropower dams, with an installed capacity of $7207 \mathrm{MW}$, and the capacity to generate about 37,366 kilowatthours per year [24]. Most projects have been developed on the basis of the build-operatetransfer (BOT) model, in which private companies invest in projects that they have concession agreements for, and after a set period of time, often 25-30 years, the projects are handed over to the Lao government [25]. In addition, 36 hydropower dams were under various stages of construction in early 2019. They were expected to contribute $4184 \mathrm{MW}$ in installed capacity by the time they were completed at the end of 2020. Furthermore, the government of Laos was planning to begin developing another 10,000 MW of electricity by 2020, and an additional 20,000 MW by 2030 [24]. Given current projections of rapidly increasing installed capacity, and Laos' energy exports to neighboring countries, some have referred to Laos as becoming "the battery of Asia", an appellation also attributed to China's Yunnan Province because of the potential hydropower capacity there as well.

In Cambodia, the 400 MW Lower Sesan 2 Dam, the largest dam to be built in Cambodia to date, began construction in 2014, and was completed in 2018 [26,27]. Studies have also been conducted regarding the possible development of the Sambor Dam in the mainstream Mekong River [28], although reports suggest that the project has recently been set aside for at least a decade [28,29].

In China, a number of large dams were constructed on the mainstream Lancang (Mekong) River during the 2010s, including the massive Xiaowan and Nuozhadu Dams [30]. There are now 11 dams on the mainstream Lancang River in China [31], and other dams have also been built on tributaries of the Lancang River.

The following four sections summarize the history of hydropower dams in different geographic areas within the Mekong River Basin, highlighting the main social and environmental impacts associated with the projects discussed.

\section{Case Studies: The Social and Environmental Impacts of Hydropower Dam Development}

2.1. The 3S Sub-Basin: Sesan, Sekong, Srepok River System in Northeastern Cambodia, the Central Highlands of Vietnam, and Southern Laos

Since 2000, Cambodia has experienced strong economic growth, which has subsequently resulted in increased electricity demand. In the 2000s, the vast majority of Cambodians did not have access to electricity, with $60 \%$ of urban dwellers and only $10 \%$ of rural inhabitants having access [32], and even as of 2018, Cambodia's electrification rate was still only $60 \%$. Moreover, half of the country's rural population still lack ready access to electricity [33]. To meet this demand, the government has partially turned to hydropower. While a number of dams have been built outside of the Mekong River Basin in southern Cambodia [34], we focus on two projects within the Mekong River Basin. The first is the Yali Falls Dam, situated in the Central Highlands of Vietnam, and the second being the Lower Sesan 2 Dam, which operates as a run-of-the-river dam [35] and is situated in northeastern Cambodia. Both dams are constructed in the Sesan River Basin and have caused considerable social and environmental impacts on upstream and downstream ecologies and peoples. On 17 December 2018, Cambodia's Prime Minister Hun Sen inaugurated the Lower Sesan 2 (LS2) hydropower plant (Figure 1) [36]. LS2 has been met with considerable controversy and resistance from local peoples and their supporters since its inception $[26,37,38]$. The tendency to oppose the dam stems from the ecological and social impacts borne by people living in northeastern Cambodia downstream from the Yali Falls Dam (completed in 2001) and other dams on the Vietnamese side of the border. The transboundary and cumulative character of these projects has been an added challenge for those downstream in Cambodia [15,16,39]. 


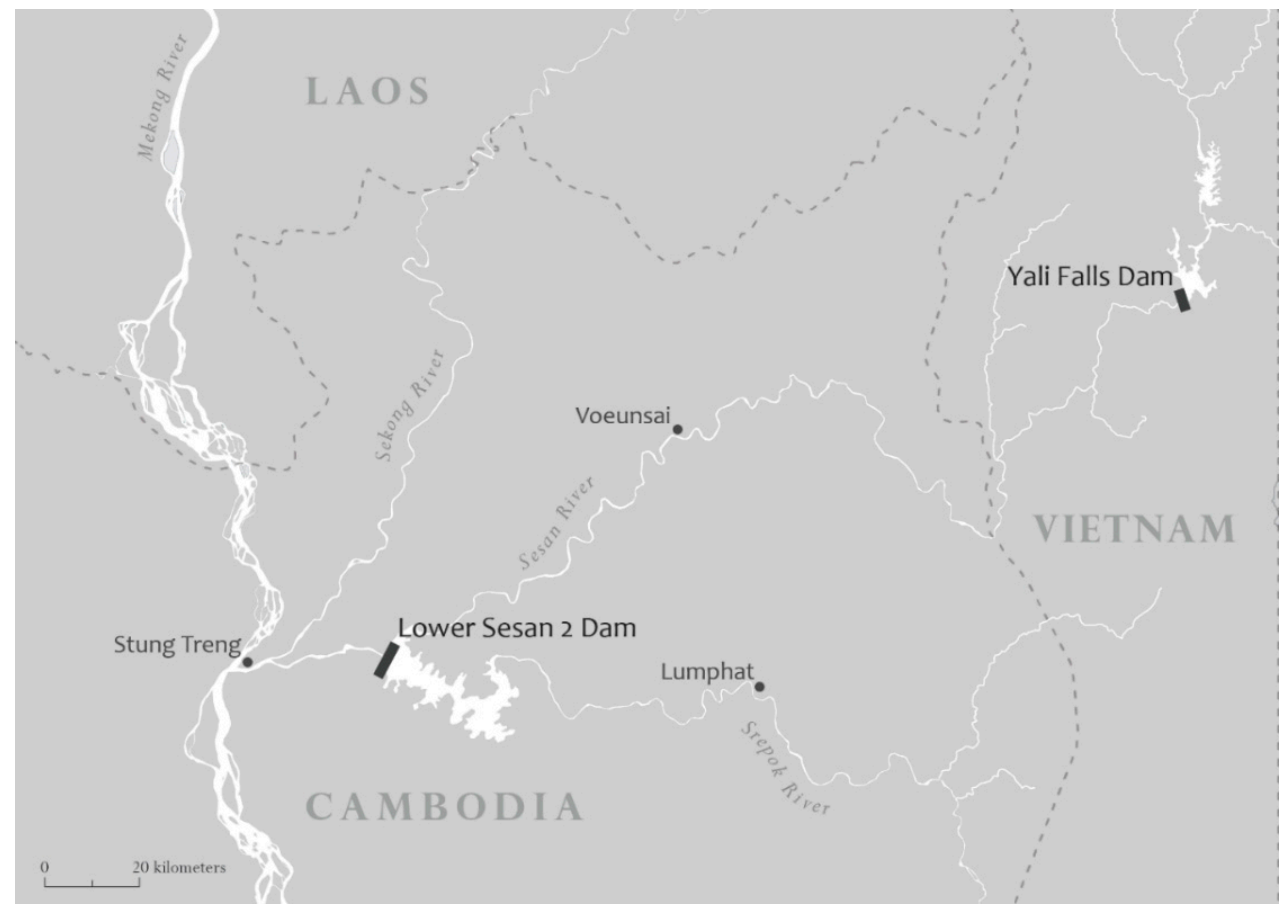

Figure 1. The Sesan River Basin, including the Yali Falls Dam and the Lower Sesan 2 Dam, northeastern Cambodia and the Central Highlands of Vietnam.

Constructed $80 \mathrm{~km}$ from the Cambodian border on the Sesan River, the 720 MW Yali Falls Dam, the largest dam in the $3 \mathrm{~S}$ system, greatly disrupted villagers' lives downstream in Cambodia (Figure 1). NGO Forum on Cambodia [39], Wyatt and Baird [15], and Hirsch and Wyatt [16] provided significant evidence of such losses. For example, unexpected strong water releases from the dam led to boats capsizing, as well as the loss of life and property, including fishing gear and boats. As many riverine communities downstream rely on fishing for food and income, these losses threatened food security and incomes in these communities. Important fish habitats, such as deep-water pools, have been silted up, and water quality in the river has changed. Fish populations have subsequently been seriously impacted [40]. Overall fish catches have declined, and it seems likely that fish spawning has been disrupted, since water quality, hydrology and habitat have all been dramatically altered. Changing water levels and riverbank erosion have also led to a reduction in riverbank gardens. Poor water quality released from the dam has also been associated with health problems including death. During construction of the Yali Falls Dam, villagers downstream in Cambodia complained of stomach infections, eye irritations, and rashes, among other ailments. Children who spent time in the river bathing and swimming were more susceptible to illness [39]. Initially, the cause of these health problems was undetermined. However, in 2009, toxic blue-green algae was confirmed to be found in the Yali Falls Dam's reservoir in Vietnam. It is believed to have been the cause of people and domestic and wild animals falling ill and dying [41-43]. Changes to the river have been meet with fear and uncertainty. Some families even moved inland to forested areas or agricultural lands, creating other types of land-based environmental impacts [16].

Adding to the impacts of the Yali Falls Dam has been the newly constructed LS2 Dam. While people living below LS2 face similar downstream issues to those living downstream from the Yali Falls, those located above LS2 inside and outside of the reservoir area are facing a different set of problems. While some villagers insisted on remaining near their former villages, relocating to higher ground, others reluctantly agreed to resettlement packages. The suitability of resettlement sites remains a serious problem for those displaced. These villagers continue to worry about loss of agricultural and forest lands, lands for grazing, and the long distances they live from perennial water bodies. Deforestation 
rates in the area have outpaced loss of forests in other parts of Cambodia, with reports of rapidly accelerating deforestation rivaling the highest rates globally [44]. Even as these concerns persist, questions about appropriate compensation also loom. Without land to cultivate and with less fish to catch, villagers have been left without alternative livelihood options. The lack of a clear governmental resettlement policy or associated legislation on resettlement and compensation remains a deficiency of the LS2 hydropower development scheme $[26,38,45,46]$. The loss of fisheries needs to be more seriously addressed, especially in areas upstream of the reservoir, where migratory fish species no longer reach in the same numbers, thus negatively impacting the food security and incomes of local people.

LS2 has long been expected to result in heavy impacts on fisheries in various parts of the basin, through blocking fish that had seasonally migrated past the site of the dam [41-47]. Baird and Flaherty [48] predicted that a number of important mid-sized carps, including Mekongina erythrospila, Scaphognathops bandanensis, Labeo erythropterus, Bangana behri, Hypsibarbus malcolmi, and Cirrhinus molitorella, which migrate between the Sesan, Srepok, and Sekong River Basins and the mainstream Mekong River, would be heavily impacted if dams were to be built on the lower parts of these rivers. Furthermore, Ziv et al. [49] estimated that the LS2 Dam would cause a 9.3\% decline in fish biomass in the Mekong River Basin, more of an impact than any other tributary dam in the basin. Arias et al. [50] have also illustrated the basin-wide hydrological impacts of dams on the 3S Basin. Dams such as the Yali Falls Dam and the LS2 Dam are impacting fisheries and communities that depend on them further south, including in the Tonle Sap Lake and the Mekong Delta in Vietnam, and further upstream in Laos and Thailand, along the Mekong River and its tributaries. These dams impede sediment and nutrient transport, causing coastal erosion in the Mekong delta, and disrupting river hydrology, which has facilitated deforestation and loss of fish production in the Tonle Sap Lake. Thus, changes such as these are affecting food security well beyond the immediate upstream and downstream communities near these dams [51]. These spatially expansive geographies and transboundary impacts need to be seriously considered but are often underestimated in environmental impact assessments and mitigation and compensation programs, especially when such assessments and programs are limited to the areas directly adjacent to dam sites or fail to consider cumulative impacts of multiple existing and planned dams [28]. A key barrier to more comprehensive and transboundary impact assessments is the uneven negotiating power among riparian countries. In the case of the Yali Falls Dam, Vietnam's unwillingness to equitably consider downstream impacts in Cambodia, along with Cambodia's weak financial and technical capacity, led to a deficient impact assessment that only considered possible impacts $6 \mathrm{~km}$ downstream [15].

\subsection{The Khone Falls Area}

Clearly visible from Cambodia's Preah Rumkel Commune in Thalaboriwatt District, Stung Treng Province, Laos' 260 MW Don Sahong Hydropower Project operates as a runof-the-river dam and is located in the Khone Falls area, a series of channels, waterfalls, and small islands in the mainstream Mekong River in Khong District, Champassak Province, southern Laos (Figure 2). The project commenced commercial operation in November 2019, with agreements to sell power to neighboring Cambodia and Thailand [52]. This section examines the geographic extent of impacts on fisheries, food security, and changing livelihoods for those in the Khone Falls area. Many years before its construction began in 2016, concerns regarding the impacts of the dam on fish and fisheries were expressed by locals and researchers [53,54]. The Khone Falls area is important for migratory fish as they seasonally pass through the Khone Falls area and move upriver to feed and spawn [3,48,54-61]. Many locals and scientists believe that a large proportion of the fish that migrate from Cambodia to Laos previously passed through the Sahong Channel, making it one of the most important migratory corridors in the entire Lower Mekong Basin [3]. However, it was this very channel where the Don Sahong Dam was constructed. 


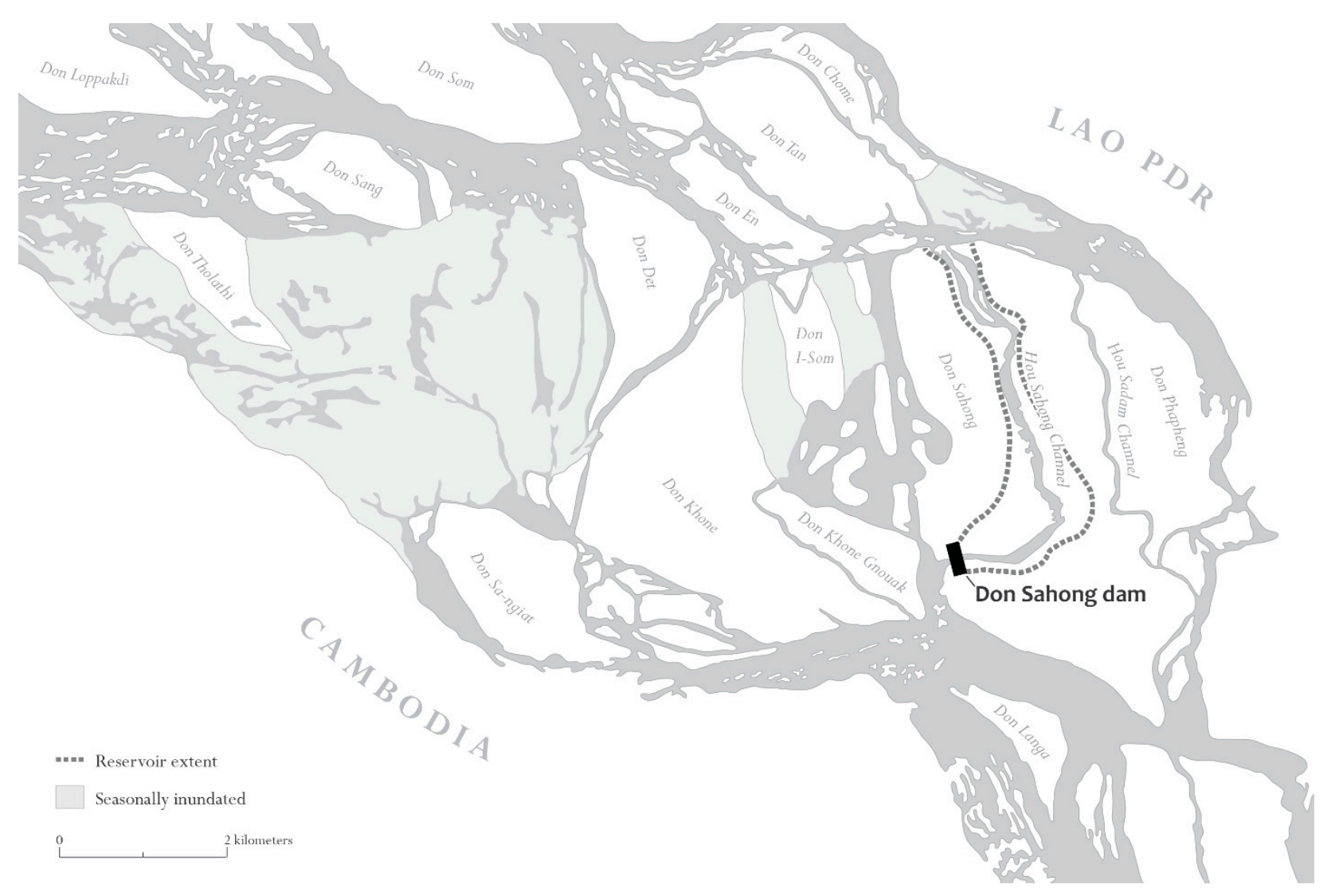

Figure 2. The Khone Falls area, including the Don Sahong Dam, in southern Laos near the border with Cambodia.

The Khone Falls area consists of varying-sized channels, and many have waterfalls on them that make it impossible for fish migrating to pass upriver. Others are only passible during certain seasons when water levels are high enough. Only the Sahong Channel was previously traversable for fish year-round, but it was especially important during the dry season due to low water levels. This was widely known by local fishers [3]. Certain fish species such as the large catfish, Pangasius krempfi, spawn in the Mekong River in Laos and Thailand but spend much of their lives in the Mekong Delta and the South China Sea in Vietnam [61]. This species has been caught in Laos' northern province of Luang Prabang, which shows that the species migrates past the Khone Falls [61]. Other important fish species such as the small and medium-sized carps that migrate north from Cambodia's Tonle Sap Lake and 3S Basin also pass through the Khone Falls before reaching the upper areas of the Mekong and its tributaries [3,48,58]. The vast number of species of fish that migrated through the Sahong Channel throughout the year made it extremely important for the ecology of the river and to local communities [3].

Locals in the Khone Falls area who rely on fish for a significant portion of their diets have seen declines in fish catches since construction of the Don Sahong Dam began. In particular, however, in order to mitigate the decline of migratory fish, large fish traps, particularly wing traps and fence-filter traps, have been banned, in order to try to mitigate the impacts of the Don Sahong Dam on upstream fish migrations. Other important fisheries in the Sahong Channel, such for migrating Pangasius macronema [57], have also been lost directly because of the dam. These traps were subject to locally developed tenure systems and were privately owned to catch migrating fish [58,59]. Collectively, these traps caught hundreds of tons of fish a year and provided food and income for thousands of people living in the Khone Falls area. While some people living upriver from the Khone Falls claim that they are now catching more fish than before, those in the Khone Falls area are facing a serious livelihood crisis, and no compensation for fisheries livelihood losses has been provided. As a result, more and more people are seeking waged labor in Thailand in order 
to support their families. It is estimated that nearly 7000 people have left Khong District to seek work in Thailand in recent years [62]. Hang Sadam Village, which is located adjacent to the dam, has been particularly negatively impacted by the ban on fishing. The people there, as well as others from nearby villages, are dependent on wild-capture fisheries for their livelihoods. Some villagers, out of frustration and desperation, have even turned to stealing from the construction site to try to make ends meet [63].

Although measures have been taken to mitigate the impacts of the Don Sahong Dam on upstream fish migrations, by opening up channels for fish to pass [64,65], it remains uncertain whether all fish will be able to travel past the Khone Falls through these smaller channels as compared to the much wider and deeper Sahong Channel. There is particular concern about larger species, such as the Critically Endangered giant catfish (Pangasianodon gigas), but also other large species such as Pangasius krempfi [66]. It is conceivable that the Don Sahong Dam has now blocked an important spawning migration for the giant catfish, isolating populations above and below the falls, and further imperiling the species. Furthermore, the owners of the Don Sahong Dam expect that about $5 \%$ of the fish that pass through the fish turbines when migrating downstream will not survive, but the impact could be much greater [67]. Such mortality rates for smaller fish have been found to be $5-25 \%$, increasing with larger-sized fish, with those longer than $50 \mathrm{~cm}$ having a $40 \%$ mortality rate and those longer than 1 meter having nearly a 100\% mortality rate [68]. Baird [69] describes measures that dam operators were initially proposing to include in order to achieve minimal impacts, including the use of screens and barriers and an acoustic fish deterrence system to keep fish away from the turbines. However, it appears that those measures have been scaled back compared to original plans. Even if such mitigation measures are put in place, the dam has already caused significant impacts on local livelihoods and is certainly going to have regional impacts on fisheries, although the exact impacts are far from certain and have not been well studied.

\subsection{The Mun River Sub-Basin}

While there are a number of dams in the Mekong River Basin in Northeast Thailand, we center our attention here on one of the most heavily studied and controversial dams in Southeast Asia, the Pak Mun Dam. We particularly consider the basin-wide impacts on the Mun River's hydrology and local livelihoods. Located on the Mun River in Ubon Ratchathani Province, northeastern Thailand, and merely $5.5 \mathrm{~km}$ from the confluence of the Mekong River (Figure 3), the Pak Mun Dam has continued to be a site of contention for many people living along the Mun River's banks and beyond. The $136 \mathrm{MW}$ dam operates as a "run-of-the-river" dam [70], but has a $60 \mathrm{~km}^{2}$ reservoir, more storage than what many would expect for a run-of-the river dam. The Pak Mun Dam is situated within the national boundaries of Thailand but drains the entire Chi-Mun River Basin into the Mekong River. Therefore, a dam on the Mun River, such as the Pak Mun Dam, is not only negatively impacting the entire region of northeastern Thailand but also downstream riparian countries such as Laos, Cambodia, and Vietnam. The perpetual struggle against the dam was in part brought on by the Thai state's continued repression of the voices of people impacted by project [7]. In the 30 years since the dam's approval, local people in many communities have experienced serious impacts, such as loss of fisheries, flooding, loss of agricultural land, and declines in community cohesion and multi-generational family connections.

For local peoples, the costs of the Pak Mun Dam far outweigh the benefits $[7,8,20,71]$. First, the dam was never meant to be part of a local or regional development project but was rather developed to supplement the national power grid of Thailand [71]. However, the Mun River and its aquatic resources are deeply rooted in the livelihoods of the communities along its banks and tributaries. Disrupting the river and changing its hydrology have had serious consequences for those communities $[7,10,20]$. In order for the project to move forward, many families had to be resettled due to the inundation of their villages and agricultural lands. In addition to the hardships that came with resettlement, many villagers 
outside of the reservoir area also face problems of declining fish catches. The Pak Mun Dam is directly responsible for these declines because it blocks migrating fish from moving between the Mun and Mekong Rivers [10,71-78]. Even with a fish ladder that was added later to mitigate the loss of migratory fish, upstream fisheries have declined. Very few fish use the fish ladder, and the disruption of, and changes to, the river's hydrology has negatively affected the livelihoods of peoples in the entire basin [76-78].

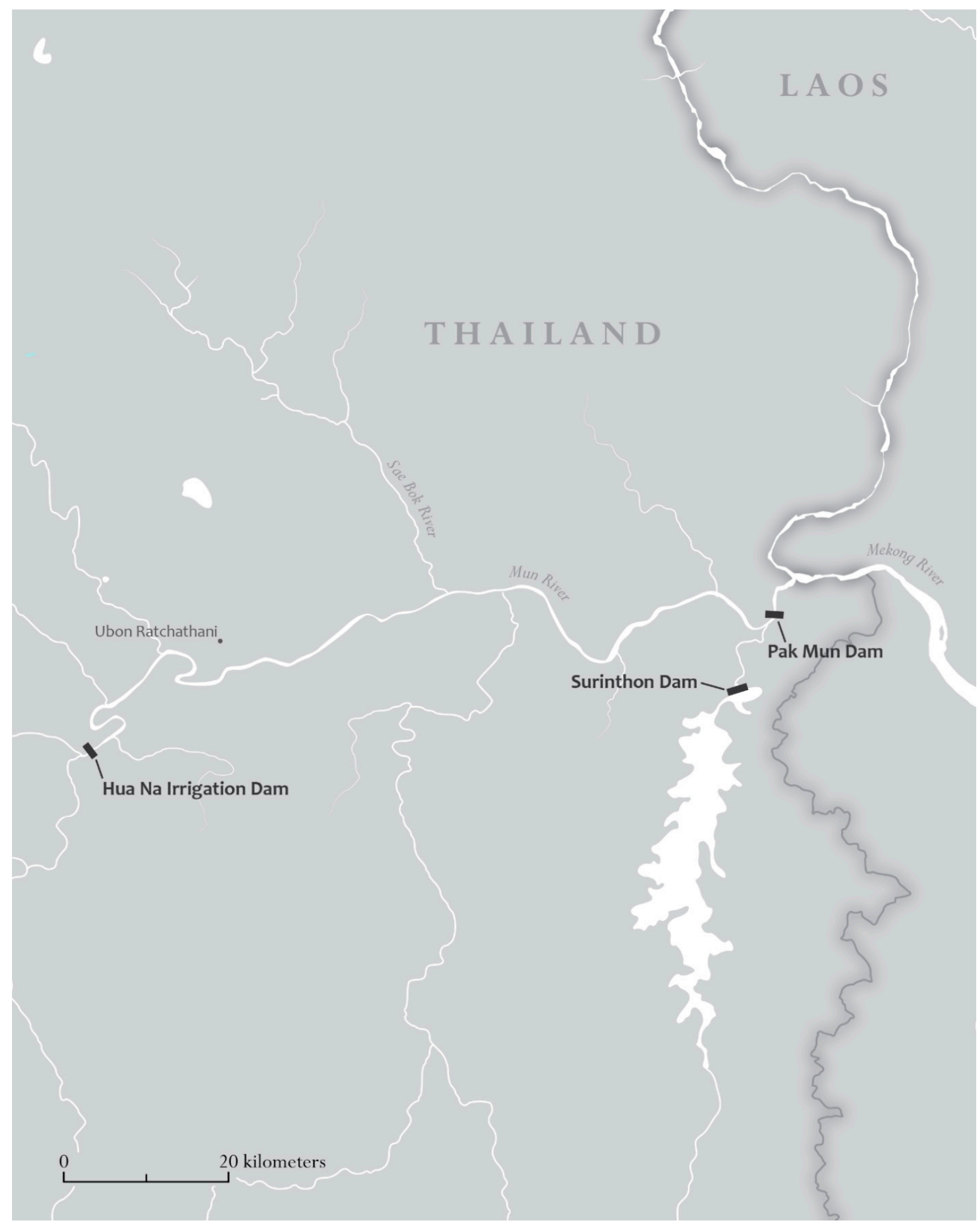

Figure 3. The Lower Mun River Basin, including the Pak Mun, Hua Na, and Surinthon dams, northeastern Thailand. 
Since completion in 1994, the Pak Mun Dam has negatively impacted large numbers of villagers. Many fishers did not submit their petitions for compensation until after local people demonstrated against the dam in 1999. Some villagers resettled before an agreement with the Electricity Generating Authority of Thailand (EGAT) was reached and, therefore, were not given compensation. Others did not expect to be in the flood zone, but later realized that the flooded areas led to new concerns for the safety of their cattle and children [71]. Problems such as these have added to the very clear failures of the Pak Mun Dam [20]. Most recently, Baird et al. [10] have demonstrated that the Pak Mun Dam has also negatively impacted fisheries in Mun River tributaries not originally considered to have been in the dam's area. It is now, however, known that the Pak Mun Dam blocks the migrations of a number of large and small long-distance migratory fish species from the Mekong River that previously migrated up the Mun River and then its tributary, the Sebok River. For example, fishers from Thalat village, on the Sebok River, reported that a number of species of fish that they used to catch each year have now mainly disappeared.

Currently, the Pak Mun Dam opens at various times during the rainy season between June and September, well after migratory fish would normally make their way up the Mun River at the beginning of the rainy season in May or early June [78]. There have been calls for opening the sluice gates for the dam year-round or, at the very least, when migratory fish begin to move upriver during the beginning of the rainy season. In 2004, the sluice gates were opened for four months beginning in May as villagers requested. However, after a military coup ended the Thaksin Shinawatra government in 2006, the gates have been opened inconsistently, following the political will of those in power [78]. Issues related to compensation for fish losses and resettlement remain unresolved. The experiences of communities in the lower Mun River Basin led to opposition of a proposed dam on the Songkhram River-now the last free-flowing tributary of the Mekong in northeastern Thailand [79].

Without fish, along with other societal changes, younger generations have stopped fishing and turned to other means to support their families. This has led to a loss of knowledge transmission. Knowledge about fishing gears and the harvesting of aquatic resources has been lost, as there are fewer people to carry on livelihoods associated with the river, resulting in the loss of important elements of local culture and identity [80]. In many villages, only the elderly and young children remain.

\subsection{Chiang Rai/Bokeo Mainstream Mekong Area}

In the northern reaches of the Mekong River Basin, China's Wunonglong, Lidi, Huangdeng, Dahuaqiao, Miaowei, Gongguoqiao, Xiaowan, Manwan, Dachaoshan, Nuozhadu, and Jinghong dams along with Laos' Xayaburi Dam have been quite controversial. While many of the social and environmental impacts of these dams occur in the upper basin in the immediate vicinity of the dams, it is important to examine their short- and long-distance downstream impacts. China currently has 11 operational dams on the Lancang River. Some are run-of-the-river dams, and some have large reservoirs and significant water storage capacity (Figure 4). The average annual discharge of the Mekong is estimated at $475 \mathrm{~km}^{3}$ [81]. The Nuoxhadu and Xiaowan Dams alone combine to store $37.5 \mathrm{~km}^{3}$ of water, approximately $8 \%$ of the total average annual discharge of the river, and a much larger proportion of the amount of water that comes from the upper basin [82]. In that China's largest Lancang dams regulate water to maximize profits from power generation, the holding back of such large volumes of water at certain times of year has had calamitous effects on downstream riparian communities. Cambodia and Vietnam, for example, have expressed concerns over silt that may be trapped behind the Lancang dams. Such silt deposits are critically important for the agricultural productivity and fisheries in the Tonle Sap lake-river system [83]. Despite the fact that the Mekong is a shared resource flowing through several Southeast Asian countries before emptying into the South China Sea, China considers water originating in China to be the sovereign property of China, rather than a resource to be shared with downstream countries [31]. This is not surprising, as China 
has a long history of non-cooperation in the Mekong Basin, at least when it comes to discussing its own plans for dam-building on the Mekong. Downstream impacts are rarely considered, and never sufficiently $[84,85]$. Within China itself, the lack of transparency and collaboration with local actors is also concerning [86].

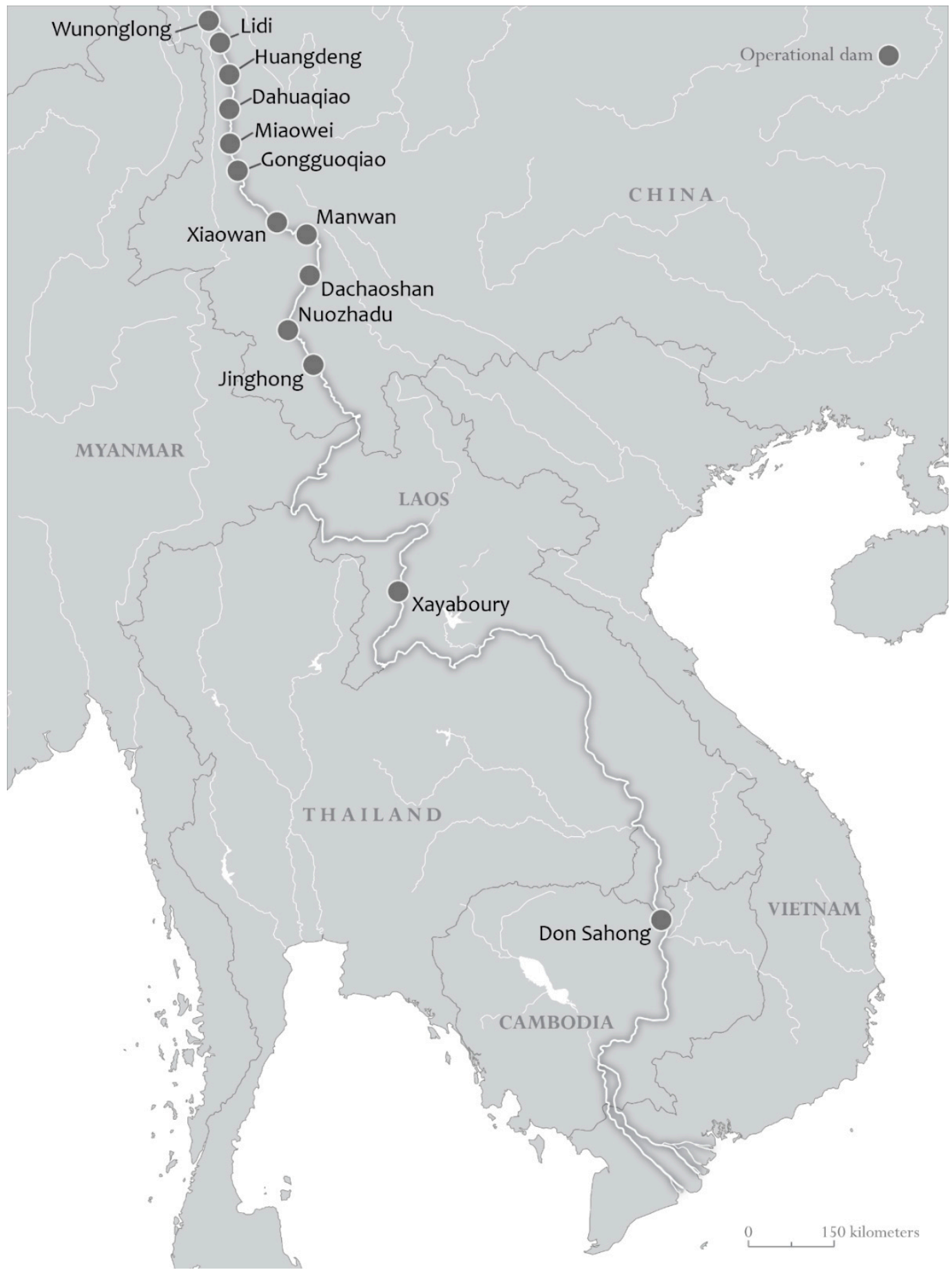

Figure 4. The Mekong River Basin, including hydropower dams built on the mainstream Mekong/Lancang River in China and Laos.

The Lancang dams (or Lancang Cascade) in the upper Mekong has caused considerable controversy for China. Socioeconomic and cultural impacts caused by human resettlement that followed construction of the Lancang dams have been well documented [85-87]. 
Unexpected and extreme changes to water levels downstream have been attributed wholly or in part to the construction of mainstream Mekong dams in China [31]. Changes such as these are affecting local livelihoods as well as food security for downstream riparian communities and have resulted in various civil society concerns [88]. Beyond the social impacts, unseasonal and sudden releases of water can cause shocks to the life cycles and migratory patterns of fish and birds [31]. Disruptions to river hydrology; unseasonable and sudden releases or constraint of flow; and accentuation of periods of low precipitation, run-off, and drought have led to multiple serious impacts for communities in the Golden Triangle area of Laos and Thailand. This includes riverbank erosion; loss of homes and riverbank gardens; loss of access to water for drinking and agriculture; loss of harvest of aquatic resources including fish, shrimp, and edible algae; and disruption of fish migration and spawning triggers, reportedly leading to declines in fish populations. These disruptions to the river's natural hydrology could be ameliorated by environmental flows, which relate to water releases from China's mainstream Mekong dams, that more closely resemble historical hydrological patterns. Given the changes in the hydrological regime in the lower Mekong region, greater consideration needs to be given for the downstream transboundary impacts of hydropower projects in China.

Apart from China, Laos has its own ambitions for dam-building on the mainstream Mekong. According to Hirsch [21], "the Lao government in particular sees no reason why it should hold back on developing a shared river when an upstream country is already doing so." Indicative of this, on 29 October 2019, Laos' 1285 MW Xayaburi Dam officially began operations. Its construction, beginning in 2012, was met with considerable criticism from both environmentalists and human rights groups. Since the dam's completion, clear blue waters have been observed downstream from the dam, indicating the river's absence of nutrients and sediments crucial for aquatic life [89]. The severe rising and falling of water levels in the river, negatively impacting fisheries, also has implications for food security downstream. The project's Environmental Impact Assessment (EIA) failed to adequately address fish biodiversity losses or the dam's impacts on local livelihoods [90,91]. An independent assessment, conducted the same year as the project's EIA focused on migratory and rare fish, concluded that, "all available evidence suggests that the Xayaburi Dam will have serious negative impacts on the migratory and imperiled fish of the lower Mekong River, and may drive the Mekong's two largest freshwater fish species, the Mekong giant catfish (Pangasianodon gigas) and the giant pangasius catfish (Pangasius sanitwongsei) to extinction" [92]. Given the available evidence presented, the project's EIA was clearly overly limited in scope and deficient in various ways. Wyatt and Baird [15] detail similar deficiencies in assessments at the Yali Falls Dam. However, despite controversy and resistance, Laos has aspirations to build even more dams on the mainstream Mekong River within its borders, including the Pak Beng Dam, the Luang Prabang Dam, and the Sanakham Dam.

While China and Laos would like to think of the upper Mekong as a national commodity $[30,84]$, the reality is that the entire Mekong basin is crucially important for the biodiversity of the region and the local economies and the food security circumstances in the downstream countries. China's unwillingness to fully cooperate with members of the Mekong River Commission (MRC) has proven to be detrimental to the efficacy of the organization. Like China, Laos has shown a desire to act unilaterally when it comes to dam-building on the Mekong. However, unlike China, Laos is a member of the MRC and "needs to temper expressions of sovereignty over the river within its own borders with an adherence to procedures for prior consultation agreed to for projects with potential transboundary impacts" [21]. The uneven power geographies here are also important to consider. A number of scholars have explored the relationships between national and regional governments, non-governmental organizations, private hydropower companies, and local actors in the Mekong River Basin, finding that the social dimensions of hydropower development schemes are often overlooked or given inadequate consideration, especially with regards to resettlement, compensation, and the livelihoods of local peoples $[27,86,87,93,94]$. 


\section{Discussion}

All four of the above case studies illustrate the importance of thinking about the different and expansive geographies of hydropower dams in the Mekong River Basin, especially those related to cumulative social and environmental impacts [95-97]. These dams have disrupted the hydrology of the Mekong River and its tributaries. Unseasonal changes to water levels, flow rates, and turbidity are having ecologically negative synergistic effects, not only on areas immediately nearby these hydropower projects, but also on places many $\mathrm{km}$ away in neighboring countries. These impacts are compounded with each new dam constructed, further stressing the hydrology of the river and its tributaries, the biological life it supports, and the peoples' dependence on it for their livelihoods. Adding to the complexity of these geographies are those related to decision-making and energy production, energy transfer, and consumption processes that often transcend national borders and have uneven repercussions for local peoples.

Following the World Commission on Dams report in 2000 [20], hydropower development lost considerable international support. However, hydropower has seen a resurgence in recent years. To meet the needs of urbanization and development, as well as climate change mitigation, hydropower energy is now seen by some as a suitable alternative to fossil fuels [98]. Hydropower development, particularly in the developing regions of southern China and Southeast Asia, is thus being once again viewed by some as a viable answer to meet the growing demand for energy. Framed as "clean" and "green", hydropower development has captured the attention of funding institutions such as the Asian Development Bank, the World Bank, various private banks, national government in Asia, and private corporate investors [99]. Climate change mitigation has certainly captured the imagination of hydropower developers and hydropower-developing nations. In particular, the Clean Development Mechanism (CDM), first introduced under the 1997 Kyoto Protocol, has become a popular way to fund hydropower development in the region [34,99]. However, market prices for carbon credits have fallen dramatically, making it uneconomical for newer dam projects such as the LS2 in Cambodia to apply for CDM funding [34]. Despite the perceived benefits that hydropower dams provide, global hydropower development has proven socially and environmentally disastrous $[20,31,93,95]$. Studies have shown that hydropower would contribute less than $50 \%$ of the world's electricity demands even if the entire technically feasible hydropower potential of the world's basins were exploited [100]. It should be of considerable concern that many national governments in the Mekong River Basin have focused on hydropower development and have utilized climate change mitigation, when convenient, to rationalize dam development. In reality, gross greenhouse gas emissions from dam reservoirs, dam construction, and subsequent land use and livelihood changes can be higher than thermal alternatives in tropical and boreal regions [20,99]. As a growing number of governments subscribe to the "greening" of hydropower, it is evermore necessary to consider regional cooperation in critiquing the role of dams in climate change mitigation. Other alternatives, such as solar and wind power, make a lot more sense, economically, socially, and environmentally [101-104].

The particular seasonal hydrological changes that have historically occurred in both the mainstream Mekong and its tributaries are ecologically important for the sustainability of aquatic life. They create various fish habitats from deep water pools to flooded forests [3]. Hydropower dams along the length of the Mekong River and its tributaries are, however, severely disrupting these hydrological patterns and sediment transfers. Restoring these flows would have a significant positive impact on downstream ecosystems [105]. As discussed above, China's Lancang cascade of dams have already altered the river's natural hydrology [106-110], impacting both aquatic species dependent on certain habitats and seasonal changes to the river for migration and spawning [10,57]. The second author has observed that some flooded forests along the mainstream Mekong River in Stung Treng Province are no longer being exposed to the air for at least part of the year and have thus died. Severe droughts and floods are also associated with changes to the river's hydrology, impacting local peoples dependent on the river and its tributaries for food and 
their livelihoods. It is clear that site-based impact assessments of hydropower projects are insufficient, as dams often have basin-wide impacts. As such, cumulative impacts need to be considered much more carefully.

The impact on the 65 million people who rely on the Mekong and its tributaries for food and their livelihoods can no longer be overlooked. Hydropower dams block fish migrations and negatively affect fisheries downstream, consequently impacting fisheries, food security, and the health of people throughout the basin [3]. For the many riparian communities living along the Mekong River and its tributaries, hydropower dams are leading to continued losses of fish and fisheries, riverbank gardens, ecotourism opportunities, and fertile land for agricultural cultivation. Fisheries losses alone could amount to USD 500 million per year, equivalent to the total average annual income of hundreds of thousands of households in the region [111-114]. By 2040, the decline of fisheries could cost almost USD 23 billion [115]. Moreover, the livelihood geographies of people in the basin are being dramatically affected. Indicative of this, there is already much evidence of outmigration from the Khone Falls area [62] and from the Mun River communities [79] to seek waged labor in urban areas. Such outmigration impacts various groups in different ways. Brown et al. [87] detail the impacts related to China's ethnic minorities' difficulties in seeking waged labor due to inadequate language and technical skills. Related disruptions to social networks, economic opportunities, and other cultural impacts as a result of resettlement have also been studied $[41,86]$. Around the Tonle Sap Lake, a region of historically bountiful fish catches and high per capita rates of fish consumption, communities are shifting to harvesting mollusks and to cultivating small-scale agriculture as fish stocks decline. Such impacts on food and economic security are rarely considered beyond the immediate areas of hydropower dam project sites [29]. Therefore, dam developers and national governments need to better address the wider geographies of already existing and future dam development.

The process of constructing a hydropower dam is certainly complex and geographically expansive. As we have argued, dam developers and governments in the Mekong River Basin need to consider both local and basin-wide impacts. This can be difficult as national interests often outweigh impacts incurred by upstream and downstream neighbors, as was clearly evident in the case of the Yali Falls Dam [15]. In the Mekong River Basin, dam sites are often situated in remote areas while the energy produced from them is consumed in urban areas both within national boundaries and in neighboring countries. The geographies of hydropower energy production and consumption, and the linkages between them, are thus important for understanding the unevenness that such linkages assemble. Magee [19] and Hennig et al. [116] conceptualize hydropower dam geographies as "powersheds" in order to illustrate the uneven costs and benefits and linkages between resource-rich Yunnan Province and the highly urbanized Guangdong Province in need of hydroelectric power. Similarly, Baird and Quastel [105] have used a political ecology approach to examine the linkages between Bangkok's (Thailand) air conditioning usage, fluctuating water releases from the Nam Theun 2 Dam, and the changing hydrology of the Xe Bang Fai River in Laos. Examples of such processes and connections expand the geographies of impacts beyond localized dam sites. Understanding these geographies can be critically important for addressing the unevenness of injustices that these geographies oftentimes produce.

\section{Conclusions}

Although it has long been recognized that hydropower dam development in the Mekong River Basin has the potential to cause serious social and environmental impacts, including impacts far away $[3,48,49,58,117]$, there is mounting evidence suggesting that insufficient attention is being paid to the cumulative and large-scale impacts on fish species, people, and places that are adversely affected by dams. Illustrative of this, Green and Baird [28] have recently argued that the spatial extent of impacts has often been underestimated in practice, including with regard to the Pak Mun Dam in northeastern 
Thailand; the LS2 Dam in northeastern Cambodia; or the Sambor Dam, which has been proposed for the mainstream Mekong River in northeastern Cambodia.

It is clearly crucial to consider the geographies of the social and environmental impacts of dam development in the Mekong River Basin and to seriously evaluate the winners and losers of such projects, including beyond national borders, as those who are losing out have much less influence and wealth than those who are benefiting from hydropower dam development. In particular, we need to more critically assess the transboundary and cumulative impacts of dams on biodiversity and fish migration, as well as on those communities most negatively impacted by these projects. Consideration of such expansive geographies in the Mekong River Basin will serve to inform other basins of potential impacts. The Congo River and Amazon River Basins, too, have seen similar impacts—reduced water downstream flows, displaced populations, and deforestation [117]. In addition, we need to strengthen and expand extraterritorial regulations and enforcement bodies charged with social and environmental assessments [46]. A new tool for monitoring the Mekong River Basin and environmental impacts is an open-source online platform called the Mekong Dam Monitor (https:/ / www.stimson.org/project/mekong-dam-monitor/), which makes available various data on the Mekong for scholars, policy makers, and citizens. While information may be a first step, strengthening regulatory and enforcement bodies such as the MRC are also important, albeit a more difficult step. Regional interests need to be taken more seriously in national hydropower development processes. As climate change is a very present reality, it has the potential to serve as the axis around which riparian countries can gravitate, resulting in thinking about the serious social and environmental impacts that hydropower development is having in the basin. In any case, before any of these measures are likely to be taken seriously, we have to better understand the expansive geographies of the social and environmental impacts of hydropower dam development in the Mekong region.

Author Contributions: Conceptualization, A.S., I.G.B. and Z.S.H.; methodology, A.S., I.G.B. and Z.S.H.; investigation, A.S. and I.G.B.; writing-original draft preparation, A.S. and I.G.B.; writingreview and editing, A.S., I.G.B. and Z.S.H.; visualization, I.G.B. and A.S.; supervision, I.G.B. and Z.S.H.; project administration, I.G.B. and Z.S.H.; funding acquisition, I.G.B. and Z.S.H. All authors have read and agreed to the published version of the manuscript.

Funding: Z.S.H. was funded by the United States Agency for International Development (USAID)supported project, Wonders of the Mekong (Cooperative Agreement \# AID-OAA-A-16-00057). I.G.B. and A.S. were funded by the Tracking Changes Project, funded through the University of Alberta by the Social Sciences and Humanities Research Council (SSHRC) of Canada.

Institutional Review Board Statement: Not applicable.

Informed Consent Statement: Not applicable.

Data Availability Statement: No new data were created or analyzed in this study. Data sharing is not applicable to this article.

Acknowledgments: The authors acknowledge the administrative support of the University of Wisconsin-Madison and the University of Nevada Reno College of Science, Department of Biology, and Global Water Center. Austin Novak, with data provided by Ian G. Baird, from the Cartography Lab at the Department of Geography, University of Wisconsin-Madison, prepared the maps.

Conflicts of Interest: The authors declare no conflict of interest. The funders had no role in the design of the study; in the collection, analyses, or interpretation of data; in the writing of the manuscript; or in the decision to publish the results.

\section{References and Note}

1. Shaochuang, L.; Lu, P.; Liu, D.; Jin, P. Pinpointing source of Mekong and measuring its length through analysis of satellite imagery and field investigations. Geo-Spat. Inf. Sci. 2007, 10, 51-56.

2. Mekong River Commission (MRC). Available online: https://mrcmekong.org/about/mekong-basin/people/ (accessed on 30 December 2020). 
3. Baird, I.G. The Don Sahong dam: Potential impacts on regional fish migrations, livelihoods and human health. Crit. Asian Stud. 2011, 43, 211-235. [CrossRef]

4. Molle, F.; Floch, P.; Promphakping, B.; Blake, D.J.H. The 'greening of Isaan': Politics, ideology and irrigation development in the northeast of Thailand. In Contested Waterscapes in the Mekong Region: Hydropower, Livelihoods and Governance; Molle, F., Foran, T., Käkönen, M., Eds.; Eartchscan: London, UK, 2009; pp. 253-282.

5. Hirsch, P. The changing political dynamics of dam building on the Mekong. Water Altern. 2010, 3, 312-323.

6. Sneddon, C. Concrete Revolution: Large Dams, Cold War Geopolitics, and the US Bureau of Reclamation; University of Chicago Press: Chicago, IL, USA, 2015.

7. Foran, T.; Manorom, K. Pak Mun Dam: Perpetually contested. In Contested Waterscapes in the Mekong Region: Hydropower, Livelihoods and Governance; Molle, F., Foran, T., Käkönen, M., Eds.; Earthscan: London, UK, 2009; pp. 55-80.

8. Missingham, B.D. The Assembly of the Poor in Thailand: From Local Struggles to National Protest Movement; Silkworm Books: Chiang Mai, Thailand, 2003.

9. Sneddon, C. Reconfiguring scale and power: The Khong-Chi-Mun Project in northeast Thailand. Environ. Plan. 2003, 35, 2229-2250. [CrossRef]

10. Baird, I.G.; Manorom, K.; Phenow, A.; Gaja-Svasti, S. What about the tributaries of the tributaries? Fish migrations, fisheries, dams and fishers' knowledge in north-eastern Thailand. Int. J. Water Res. Dev. 2020, 36, 170-199. [CrossRef]

11. International Rivers Network. Power Struggle: The Impacts of Hydro-Development in Laos; International Rivers Network: Berkeley, CA, USA, 1999.

12. Baird, I.G. Remembering old homes: The Houay Ho Dam, the resettlement of the Heuny (Nya Heun), and the struggle for space. In Interactions with a Violent Past: Reading Post-Conflict Landscapes in Cambodia, Laos, and Vietnam; Tappe, O., Pholsena, V., Eds.; University of Singapore Press: Singapore, 2013; pp. 241-263.

13. Whitington, J. Anthropogenic Rivers: The Production of Uncertainty in Lao Hydropower; Cornell University Press: Ithaca, NY, USA, 2018.

14. Fu, K.D.; He, D.M.; Lu, X.X. Sedimentation in the Manwan reservoir in the Upper Mekong and its downstream impacts. Quart. Int. 2008, 186, 91-99. [CrossRef]

15. Wyatt, A.B.; Baird, I.G. Transboundary impact assessment in the Sesan River Basin: The case of the Yali Falls dam. Int. J. Water Resour. Dev. 2007, 23, 427-442. [CrossRef]

16. Hirsch, P.; Wyatt, A.B. Negotiating local livelihoods: Scales of conflict in the Se San River Basin. Asia Pacific Viewopoint. 2004, 45, 51-68. [CrossRef]

17. International Rivers Network. Power Surge: The Impacts of Rapid Dam Development in Laos; International Rivers: Berkeley, CA, USA, 2008.

18. Baird, I.G. Catastrophic disasters and slow violence: Thinking about the Impacts of the Xe Pian Xe Namnoy Hydropower dam in southern Laos. J. Peasant Stud. 2020. [CrossRef]

19. Magee, D. Powershed Politics: Hydropower and interprovincial relations under Great Western Development. China Q. 2006, 185, 23-41. [CrossRef]

20. WCD (World Commission on Dams). Dams and Development: A New Framework for Decision-Making; Earthscan Publications: London, UK, 2000.

21. Hirsch, P. China and the cascading geopolitics of Lower Mekong Dams. Asia-Pac. J. 2011, 9, 1-5.

22. Porter, I.C.; Shivakumar, J. Doing a Dam Better: The Lao People's Democratic Republic and the Story of the Nam Theun 2; The World Bank: Washington, DC, USA, 2011.

23. Shoemaker, B.; Robichaud, W. Dead in the Water: Global Lessons from the World Bank's Model Hydropower Project in Laos; University of Wisconsin Press: Madison, WI, USA, 2018.

24. Xinhua. Available online: http://www.xinhuanet.com/english/asiapacific/2019-02/14/c_137821006.htm (accessed on 30 November 2020).

25. Wyatt, A.B. Infrastructure Development and BOOT in Laos and Vietnam: A Case Study of Collective Action and Risk in Transitional Developing Economies. Ph.D. Thesis, University of Sydney, Sydney, Australia, 2004.

26. Baird, I.G. Non-government organizations, villagers, political culture and the Lower Sesan 2 dam in northeastern Cambodia. Crit. Asian Stud. 2016, 48, 257-277. [CrossRef]

27. Cheang, S. Cambodia's Biggest Hydropower Dam Now Producing Electricity. Available online: https://WDRD.com (accessed on 17 December 2018).

28. Green, W.N.; Baird, I.G. The contentious politics of hydropower dam impact assessments in the Mekong River Basin. Political Geography 2020, 83, 1-12, (Published online). [CrossRef]

29. Reuters. Available online: https://www.reuters.com/article/us-mekong-river-cambodia/cambodia-halts-mainstream-mekongriver-dam-plans-for-10-years-official-says-idUSKBN215187 (accessed on 1 December 2020).

30. Chen, X.; Zheng, Y.; Xu, B.; Wang, L.; Han, F.; Zhang, C. Balancing competing interests in the Mekong River Basin via the operation of cascade hydropower reservoirs in China: Insights from systems modeling. J. Clean. Prod. 2020. (published online). [CrossRef]

31. Eyler, B.; Weatherby, C. New Evidence: How China Turned off the Tap on the Mekong River; Stimson Center: Washington, DC, USA, 2020. 
32. Ministry of Industry, Mines and Energy. Renewable Energy, Energy Efficiency and Energy Conservation-CDM Considerations; Department of Energy Technique; Unpublished Work; 2008.

33. Ariffin, E. Available online: https://theaseanpost.com/article/achieving-universal-electricity-access-cambodia-1 (accessed on 24 June 2018).

34. Baird, I.G.; Green, W.G. The Clean Development Mechanism and large dam development: Contradictions associated with climate financing in Cambodia. Clim. Chang. 2020, 161, 365-383. [CrossRef]

35. Note: "Run-of-the-River" dam refers to dams where the rate of water flowing into the dam equals the rate of water flowing out of the dam over a certain period of time.

36. RFA (Radio Free Asia). Available online: https://www.rfa.org/english/news/cambodia/incitement-12172018160314.html (accessed on 29 November 2020).

37. Hensengerth, O. Regionalism, identity, and hydropower dams: The Chinese-built Lower Sesan 2 Dam in Cambodia. J. Curr. Chin. Aff. 2017, 46, 85-118. [CrossRef]

38. Chu, T. Riparians versus the State in Southeast Asia: Human Security and Hydropower Struggles along the Mekong's Sesan Tributary. Asian Survey. 2017, 57, 1086-1109. [CrossRef]

39. NGO Forum on Cambodia. Down River: The Consequences of Vietnam's Se San River Dams on Life in Cambodia and Their Meaning in International Law; NGO Forum on Cambodia: Phnom Penh, Cambodia, 2005.

40. Baird, I.G.; Mean, M. Sesan River Fisheries Monitoring in Ratanakiri Province, Northeast Cambodia: Before and After the Construction of the Yali Falls Dam in the Central Highlands of Viet Nam; Sesan Protection Network: Banlung, Cambodia, 2005.

41. Baird, I.G. Best Practices in Compensation and Resettlement for Large Dams: The Case of the Planned Lower Sesan 2 Hydropower Project in Northeastern Cambodia; Rivers Coalition in Cambodia (RCC): Phnom Penh, Cambodia, 2009.

42. SWECO Grøner (in association with the Norwegian Institute for Water Research, ENVIRO-DEV and ENS Consult). Environmental Impact Assessment on the Cambodian Part of the Se San River due to Hydropower Development in Vietnam; Prepared for Power Engineering Consulting Company (PECC1); Electricity Vietnam: Hanoi, Vietnam, 2006.

43. Tiodolf, A.M. Limnological Study of the Se San River in Cambodia: Focus on Toxic Algae; STRIVER: Oslo, Norway, 2008.

44. Lohani, S.; Dilts, T.E.; Weisberg, P.J.; Null, S.E.; Hogan, Z.S. Rapidly Accelerating deforestation in Cambodia's Mekong River Basin: A comparative analysis of spatial patterns and drivers. Water 2020, 12, 2191. [CrossRef]

45. KCC (Key Consultants Cambodia). Environment Impact Assessment on Fisheries Natural Resources of Sesan 2 Hydropower Plant Project; Key Consultants Cambodia Report: Phnom Penh, Cambodia, 2009.

46. Hirsch, P. Scaling the environmental commons: Broadening our frame of reference for transboundary governance in Southeast Asia. Asia Pac. Viewp. 2020, 61, 190-202. [CrossRef]

47. Halcrow, W. Final Report: Sekong-Sesan and Nam Theun River Basins Hydropower Study; ADB TA No. 5679-REG. Unpublished Report; 1999.

48. Baird, I.G.; Flaherty, M.S. Beyond national borders: Important Mekong River medium sized migratory carps (Cyprinidae) and fisheries in Laos and Cambodia. Asian Fish. Sci. 2004, 17, 279-298.

49. Ziv, G.; Baran, E.; Nam, S.; Rodríguez-Iturbe, I.; Levin, S.A. Trading-off fish biodiversity, food security, and hydropower in the Mekong River Basin. Proc. Natl. Acad. Sci. USA 2012, 109, 5609-5614. [CrossRef] [PubMed]

50. Arias, M.E.; Piman, T.; Lauri, H.; Cochrane, T.A.; Kummu, M. Dams on Mekong tributaries as significant contributors of hydrological alterations to the Tonle Sap floodplain in Cambodia. Hydrol. Earth Syst. Sci. Discuss 2014, 11, 2177-2209. [CrossRef]

51. IFREDI (Inland Fisheries Research and Development Institute). Food and Nutrition Security Vulnerability to Mainstream Hydropower Dam Development in Cambodia; IFREDI, Fisheries Administration, Ministry of Agriculture, Forestry and Fisheries: Phnom Penh, Cambodia, 2012.

52. Laotian Times. Available online: https://laotiantimes.com/2019/11/18/don-sahong-hydropower-project-comes-online/ (accessed on 18 November 2019).

53. Hill, M.T.; Hill, S.A. Fisheries Ecology and Hydropower in the Mekong River; Mekong Secretariat: Bangkok, Thailand, 1994.

54. Roberts, T.R.; Baird, I.G. Traditional fisheries and fish ecology on the Mekong River at Khone Waterfalls in southern Laos. Nat. Hist. Bull. Siam Soc. 1995, 43, 219-262.

55. Warren, T.J.; Chapman, G.C.; Sinhanouvong, D. The upstream dry-season migration of some important fish species in the lower Mekong River of Southern Lao PDR. Asian Fish. Sci. 1998, 11, 239-251.

56. Warren, T.J.; Chapman, G.C.; Sinhanouvong, D. The wet-season movements and general biology and important fish species at the great waterfall fault line on the lower Mekong River of the Lao, P.D.R. Asian Fish. Sci. 2005, 18, 225-240.

57. Baird, I.G.; Hogan, Z.; Phylavanh, B.; Moyle, P. A communal fishery for the migratory catfish Pangasius macronema in the Mekong River. Asian Fish. Sci. 2001, 14, 25-41.

58. Baird, I.G.; Flaherty, M.S.; Phylavanh, B. Rhythms of the river: Lunar phases and migrations of small carps (Cyprinidae) in the Mekong River. Nat. Hist. Bull. Siam Soc. 2003, 51, 5-36.

59. Baird, I.G.; Flaherty, M.S.; Phylavanh, B. Mekong River Pangasiidae catfish migrations and the Khone Falls wing trap fishery in southern Laos. Nat. Hist. Bull. Siam Soc. 2004, 52, 81-109.

60. Baran, E.; Baird, I.G.; Cans, G. Fisheries bioecology in the Khone Falls area (Mekong River, Southern Laos). In Bioecology of Khone Falls Fisheries (Mekong River, Southern Laos); Worldfish Center: Penang, Malaysia, 2005; 80p. 
61. Hogan, Z.; Baird, I.G.; Radtke, R.; Vander Zanden, M.J. Long distance migration and marine habitation in the Asian catfish, Pangasius krempfi. J. Fish Biol. 2007, 71, 818-832. [CrossRef]

62. RFA (Radio Free Asia). Available online: https://www.rfa.org/english/news/laos/mekong-fish-depletion-laos-10242019155759 .html (accessed on 29 November 2020).

63. Baird, I.G.; University of Wisconsin-Madison, Madison, WI, USA. Stealing was reported by a Don Sahong Power Company employee, and confirmed by villagers in Hang Sadam Village. Personal Communication, 2019.

64. Fish can migrate through several Siphandone channels: Scientists. Vientiane Times, 9 August 2014.

65. Hawkins, P.R.; Hortle, K.G.; Phommanivong, S.; Singsua, Y. Underwater video monitoring of fish passage in the Mekong River at Sadam Channel, Khone Falls, Laos. River Res. Appl. 2018, 34, 232-243. [CrossRef]

66. Kottelat, M.; Baird, I.G.; Kullander, S.O.; Ng, H.H.; Parenti, L.R.; Rainboth, W.J.; Vidthayanon, C. The status and distribution of freshwater fishes of Indo-Burma. In The Status and Distribution of Freshwater Biodiversity in Indo-Burma; Allen, D.J., Smith, K.G., Darwall, W.R.T., Eds.; IUCN: Cambridge, UK; Gland, Switzerland, 2012; pp. 36-65.

67. National Consulting Company. Available online: https://www.mrcmekong.org/assets/Other-Documents/Don-Sahong/ DSHPP-EIA-FINAL.pdf (accessed on 29 November 2020).

68. Halls, A.S.; Mrigesh, K. Modelling the Cumulative Effects of Mainstream Hydropower Dams on Migratory Fish Populations in the Lower Mekong Basin; Mekong River Commission: Phnom Penh, Cambodia, 2009.

69. Baird, I.G. The Don Sahong Dam: Political ecology and the changing spatialities of impacts on fisheries and people in Laos. Unpublished Work, 2021.

70. Roberts, T.R. Mekong mainstream hydropower dams: Run-of-the-river or ruin-of-the-river? Nat. Hist. Bull. Siam Soc. 1995, 43, 9-19.

71. Amornsakchai, S.; Annez, P.; Vongvisessomjai, S.; Choowaew, S.; Thailand Development Research Institute; Kunurat, P.; Nippaporn, J.; Schouten, R.; Sripatrprasite, P.; Vaddhanaputhi, C.; et al. Pak Mun Dam, Mekong River Basin, Thailand: A WCD Case Study Prepared as an Input to the World Commission on Dams; World Commission on Dams: Cape Town, South Africa, 2000.

72. Jutagate, T.; Lamkom, T.; Satapornwanit, K.; Naiwinit, W.; Petchuay, C. Fish species diversity and ichthyomass in Pak Mun Reservoir, five years after impoundment. Asian Fish. Sci. 2001, 14, 417-425.

73. Jutagate, T.; Krudpan, C.; Ngamsnae, P.; Payooha, K.; Lamkom, T. Fisheries in the Mun River: A one-year trial of opening the sluice gates of the Pak Mun dam, Thailand. Kasetsart J. Sci. Technol. 2003, 37, 101-116.

74. Jutagate, T.; Krudpan, C.; Ngamsnae, P.; Lamkom, T.; Payooha, K. Changes in the fish catch during the trial of opening the sluice gates of a run-of-the-river reservoir in Thailand. Fish. Manag. Ecol. 2005, 12, 57-62. [CrossRef]

75. Jutagate, T.; Thapanand, T.; Tabthipwan, P. Is sluice gate management beneficial for spawning migrations? The case of the shark catfish (Heliocophagus waandersii) in the Mun River below the Pak Mun dam, Thailand. River Res. Appl. 2007, 23, 87-97. [CrossRef]

76. Roberts, T. On the river of no returns: Thailand's Pak Mun Dam and its fish ladder. Nat. Hist. Bull. Siam Soc. 2001, 49, 189-230.

77. Sripatrsite, P. Effects of Fish Ladder on Migratory Fish Species and Fisheries in the Pak Mun Dam. Ph.D. Thesis, Asian Institute of Technology, Bangkok, Thailand, 2005.

78. Baird, I.G.; Manorom, K.; Phenow, A.; Gaja-Svasti, S. Opening the gates of the Pak Mun Dam: Fish migrations, domestic water supply, irrigation projects and politics. Water Altern. Interdiscip. J. WaterPolitics Dev. 2020, 13, 141-159.

79. Sasaki, T.; Worrapornpan, S.; Seesang, S. Seasonally flooded community forest on the banks of the Songkhram River: A research framework. In Forest Environments in the Mekong River Basin; Sawada, H., LaFrankie, J.V., Araki, M., Shimizu, A., Chappell, N.A., Eds.; Springer: Tokyo, Japan, 2007; pp. 179-186.

80. Mekong Commons. Pak Mun Dam: 25 Years after World Bank's Loan, Problems Remain. Available online: http://www. mekongcommons.org/pak-mun-dam-25-years-world-banks-loan-problems-remains / (accessed on 3 May 2016).

81. Mekong River Commission (MRC). Available online: https://mrcmekong.org/about/mekong-basin/geography / (accessed on 30 December 2020).

82. Binh, D.V.; Kantoush, S.; Sumi, T.; Mai, N.P. Impact of Lancang cascade dams on flow regimes Vietnamese Mekong Delta. J. Jpn. Soc. Civ. Eng. Ser. 11 (Hydraul. Eng.) 2018, 74, 487-492. [CrossRef]

83. Magee, D. China Fails to Build Trust with Mekong Neighbours. 2013. Available online: https://www.thethirdpole.net/2013/07/ 24/china-fails-to-build-trust-with-mekong-neighbours / (accessed on 29 December 2020).

84. Keskinen, M.; Nehtonen, K.; Varis, O. Transboundary cooperation vs. internal ambitions: The role of China and Cambodia in the Mekong region. In International Water Security: Domestic Threats and Opportunities; Nevelina, I., Pachova, M.N., Libor, J., Eds.; United Nations University Press: Tokyo, Japan, 2008; pp. 79-109.

85. Santasombat, Y. The River of Life: Changing Ecosystems of the Mekong Region; Mekong Press: Chiang Mai, Thailand, 2011.

86. Tilt, B. Dams and Development in China: The Moral Economy of Water and Power; (Contemporary Asia in the World); Columbia University Press: New York, NY, USA, 2015.

87. Brown, P.; Magee, D.; Xu, Y. Socioeconomic vulnerability in China's hydropower development. China Econ. Rev. 2008, 19, 614-627. [CrossRef]

88. Yong, M.L. Reclaiming community spaces in the Mekong River transboundary commons: Shifting territorialities in Chiang Khong, Thailand. Asia Pac. Viewp. 2020, 61, 203-218. [CrossRef]

89. RFA (Radio Free Asia) Laos. Available online: https://www.rfa.org/english/news/laos/xayaburi-dam-begins-operations-1029 2019175158.html (accessed on 29 December 2020). 
90. Baran, E.; Larinier, M.; Ziv, G.; Marmulla, G. Review of the Fish and Fisheries Aspects in the Feasibility Study and the Environmental Impact Assessment of the Proposed Xayaburi Dam on the Mekong Mainstream. WWF Greater Mekong. 2011. Available online: https://wwfeu.awsassets.panda.org/downloads/wwf_xayaburi_dam_review310311.pdf (accessed on 29 December 2020).

91. Stone, R. Dam-building threatens Mekong fisheries. Science 2016, 354, 1084-1085. [CrossRef] [PubMed]

92. Hogan, Z. Imperiled Giant Fish and Mainstream Mekong Dams in the Lower Mekong Basin: Assessment of Current Status, Threats, and Mitigation; University of Nevada: Reno, NV, USA, 2011.

93. Brown, P.; Tullos, D.; Tilt, B.; Magee, D.; Wolf, A. Modeling the costs and benefits of dam construction from a multidisciplinary perspective. J. Environ. Manag. 2009, 90, S303-S311. [CrossRef] [PubMed]

94. Tullos, D.; Brown, P.; Kibler, K.; Magee, D.; Tilt, B.; Wolf, A. Perspectives on the salience and magnitude of dam impacts for hydro development scenarios in China. Water Altern. 2010, 3, 71-90.

95. Mathews, M.D. Negative synergy: A macro perspective for environmental issues. Int. Adv. Econ. Res. 2006, 12, 424. [CrossRef]

96. Hirsch, P. The shifting regional geopolitics of Mekong Dams. Political Geogr. 2016, 51, 63-74. [CrossRef]

97. Mekong River Commission. Don Sahong Hydropower Project. Vientiane, Lao PDR. Available online: http://www.mrcmekong. org/topics/pnpca-prior-consultation/don-sahong-hydropower-project/ (accessed on 15 October 2014).

98. Grumbine, R.E.; Dore, J.; Xu, J. Mekong Hydropower: Drivers of change and governance challenges. Front. Ecol. Environ. 2012, 10, 91-98. [CrossRef]

99. Ahlers, R.; Budds, J.; Joshi, D.; Merme, V.; Zwarteveen, M. Framing hydropower as green energy: Assessing rivers and tensions in the Eastern Himalayas. Earth Syst. Dyn. 2015, 6, 195-204. [CrossRef]

100. Zarfl, C.; Lumsdon, A.E.; Berlekamp, J.; Tydecks, L.; Tockner, K. A global boom in hydropower dam construction. Aquat. Sci. 2015, 77, 161-170. [CrossRef]

101. The World Today. Available online: https:/ /www.abc.net.au/news/2015-02-24/solar-track-becoming-cheapest-energy-sourceagora-energiewende/6251322? nw=0 (accessed on 29 December 2020).

102. Vientiane Times. Available online: https://opendevelopmentmekong.net/news/attapeu-hopes-to-build-wind-power/\#!/story= post-1065037\&loc $=14.79053895,107.100769050559,7$ (accessed on 29 December 2020).

103. VOA News. Available online: https:/ / www.voanews.com/science-health/solar-surge-threatens-hydro-future-mekong (accessed on 29 December 2020).

104. Viet Ecology Foundation. Available online: https:/ /www.pv-magazine.com/2019/12/03/how-solar-could-save-the-mekong/ (accessed on 29 December 2020).

105. Baird, I.G.; Quastel, N. Re-scaling and reordering nature-society relations: The Nam Theun 2 Hydropower Dam and Laos-Thailand electricity networks. Ann. Assoc. Am. Geogr. 2015, 105, 1221-1239. [CrossRef]

106. Glassman, J. From Seattle (and Ubon) to Bangkok: The scales of resistance to corporate globalization. Environ. Plan. D Soc. Space 2002, 20, 513-533. [CrossRef]

107. Project for Ecological Recovery. Fish, Forests, and Food: Means of Livelihood in Mun River Village Communities; Project for Ecological Recovery: Bangkok, Thailand, 1993.

108. Thanhniennews. Available online: https://archive.internationalrivers.org/pt-br/node/11464 (accessed on 29 December 2020).

109. Fawthrop, T. Available online: https:/ thediplomat.com/2020/09/the-last-farewell-to-the-mighty-mekong/ (accessed on 29 December 2020).

110. Binh, D.V.; Kantoush, S.; Sumi, T. Changes to long-term discharge and sediment loads in the Vietnamese Mekong Delta caused by upstream dams. Geomorphology 2020, 353, 1-14. [CrossRef]

111. International Rivers Network. Foretelling the Mekong River's Fate: Key findings of the MRC's Strategic Environmental Assessment on Mekong Mainstream Dams; International Rivers Network: Berkeley, CA, USA, 2011; Available online: https:/ /archive. internationalrivers.org/sites/default/files/attached-files/sea_factsheet_eng.pdf (accessed on 30 December 2020).

112. ICEM. MRC Strategic Environmental Assessment (SEA) of Hydropower on the Mekong Mainstream: Summary of the Final Report; ICEM: Hanoi, Viet Nam, 2010.

113. Yoshida, Y.; Lee, H.S.; Trung, B.H.; Tran, H.; Lall, M.K.; Kakar, K.; Xuan, T.D. Impacts of mainstream hydropower dams on fisheries and agriculture in Lower Mekong Basin. Sustainability 2020, 2408. [CrossRef]

114. Burbano, M.; Shin, S.; Nguyen, K.; Pokhrel, Y. Hydrologic changes, dam construction, and the shift in dietary protein in the Lower Mekong River Basin. J. Hydrol. 2020, 581. [CrossRef]

115. Mekong River Commission (MRC). Available online: https://mrcmekong.org/our-work/topics/hydropower/ (accessed on 30 December 2020).

116. Hennig, T.; Wang, W.; Magee, D.; He, D. Yunnan's fast-paced large hydropower development: A powershed-based approach to critically assessing generation and consumption paradigms. Water 2016, 8, 476. [CrossRef]

117. Winemiller, K.O.; McIntyre, P.B.; Castello, L.; Fluet-Chouinard, E.; Giarrizzo, T.; Nam, S.; Baird, I.G.; Darwall, W.; Lujan, N.K.; Harrison, I.; et al. Balancing hydropower and biodiversity in the Amazon, Congo, and Mekong: Basin-scale planning is needed to minimize impacts in mega-diverse rivers. Science 2016, 351, 128-129. [CrossRef] [PubMed] 